UDC $821.581-1.09 \ll 11 »$

\title{
THE PROBLEM OF ATTRIBUTION IN THE SONG POETRY: THE CASE OF WU SHUJI (吳淑姬)
}

\author{
H. Dashchenko \\ Candidate of Philological Sciences, Docent, \\ Associate Professor of The Department of Oriental and English Comparative \\ Philological Studies, Oles' Honchar Dnipro National University \\ 72, Gagarin ave., Dnipro, 49000, Ukraine \\ annadashchenko78@gmail.com
}

This paper is devoted to the problem of attribution in the Song poetry using $c i$ written by Wu Shuji (吳淑姬, c. 1185?). In spite of being considered one of the "Four Greatest Female $C i$ Poets of the Song Dynasty” (“宋代四大女詞人”) her poetry is almost unknown outside China and the records about her life have raised a number of questions over the centuries. The necessity for attribution is determined by two versions of her biography, which led to the hypothesis of the existence of two women with the same name: one was from the Northern Song (北宋, 960-1127), when the other was from the Southern Song (南宋, 1127-1279).

The purpose of my article is to prove this point of view by the analysis of four $c i$, the starting point of which is the distinction between traditional and innovative in classical Chinese poetry. The correspondence of $c i$ to the "standard form" or zhengti (正體) is considered as the tradition. On the one hand, it means to have a pattern to be replicated or followed (in the way of theme, prosody, composition, images, artistic devices, etc.), and, on the other hand, a large number of $c i$ composed by this pattern. Innovation is defined as a departure from the dominant patterns and composing brand new, extraordinary $c i$.

The empirical material of this study is four $c i$ composed to the tunes "Zhu Yingtai. Jin [Form]” (“祝英台近”), “Manifold Little Hills” (“小重山”), “Regret [for] Flying Apart” (“惜分飛”) and “Everlasting Regret. Ling [Form]” (“長相思令”). The analysis has proved that they were written by different authors. The first three $c i$ are traditional in theme, prosody, composition, images, and using artistic devices, as they fully correspond to zhenti. The fourth $c i$ is far from the established pattern and has a large number of innovative elements. It significantly differs from both zhengti and the other three $c i$. It gives the reason to conclude that it was composed by the other poetess - Wu Shuji from the Southern Song.

All analyzed $c i$ have been translated into Ukrainian for the first time.

Keywords: Wu Shuji, Song dynasty, Chinese poetry, ci, zhengti, tradition, innovation.

(C) 2021 H. Dashchenko; Published by the A. Yu. Krymskyi Institute of Oriental Studies, NAS of Ukraine and the Ukrainian Association of Sinologists on behalf of The Chinese Studies. This is an Open Access article distributed under the terms of the Creative Commons Attribution License (https://creativecommons.org/licenses/by-nc-nd/4.0/). 
ПРОБЛЕМА АТРИБУЦІЇ В СУНСЬКІЙ ПОЕЗІЇ: ВИПАДОК У ШУЦЗІ (吳淑姬)

\section{Г. В. Дащенко}

Ця стаття присвячена проблемі атрибуції сунської поезії на прикладі ци, написаних У Шуцзі (吳淑姬, приблизно 1185? рік). Попри те, що вона вважається однією із «чотирьох великих поетес династії Сун у жанрі ци» (“宋代四大女詞人»), iï творчість залишається невідомою поза межами Китаю, а залишені свідчення про iii життя викликають низку питань у дослідників протягом багатьох століть. Потреба в атрибуції зумовлена наявністю двох варіантів іії біографії, що призвело до появи гіпотези про існування двох поетес з однаковим ім'ям, одна 3 яких жила за часів династії Північної Сун (北宋, 960-1127 роки), а інша - за часів династії Південної Сун (南宋, 1127-1279 роки).

Метою статті є обгрунтування цієї думки завдяки аналізу чотирьох ци, відправним пунктом якого є розмежування традиційного та новаторського у класичній китайській поезії. Під традицією я розумію відповідність створеного автором ци «стандартній формі» чженті (正體). Це означатиме наявність, з одного боку, взірця для наслідування тематики, просодії, композиції, образів, прийомів тощо, з іншого - великої кількості творів, складених за цим взірцем. Відповідно новаторство визначається як відхід від панівних взірців віршування й утворення нових, раніше небачених прикладів.

Емпіричним матеріалом цього дослідження виступають чотири ци на мелодії «Чжу Їнтай. [Форма] цзінь» (“祝英台近»), «Маленькі пагорби» (“小重山”), «Шкодую про розставання» (“惜分飛”) та 《Вічна туга у розлуці. [Форма] лін» (“長相思令”). Здійснений аналіз дозволив довести, що вони були написані різними поетесами. Перші три ци є традиційними, оскільки цілком відповідають чженті. Четвертий ци порушує усталений взірець для написання та має велику кількість новаторських елементів. Він значно вирізняється як на тлі чженті, так і порівняно із трьома іншими ци поетеси. Це дає підгрунтя для висновку щодо його приналежності до доробку іншої авторки У Шуцзі з династії Південної Сун.

Усі проаналізовані ци вперше перекладено українською мовою.

Ключові слова: У Шуцзі, династія Сун, китайська поезія, жанр ции, чженті, традиція, новаторство.

Актуальність моєї розвідки визначається насамперед трьома моментами: відсутністю, ігноруванням і упередженням. Передусім ідеться про відсутність як перекладів, так і досліджень європейськими мовами багатьох творів китайської класичної поезії. По-друге, простежується очевидне ігнорування жанру ци, розквіт якого припав на правління династії Сун (宋朝, 960-1279 pp.), на користь досліджень та перекладів творів у жанрі ши. По-третє, є всі підстави казати про гендерне упередження, унаслідок якого творчість сунських поетес досі залишається недослідженою не лише в європейських країнах та Україні, але й у самому Китаї. Тому у фокусі цієї статті перебуває одна 3 небагатьох сунських мисткинь, доля якої є вельми красномовною. 3 одного боку, iï поетичні вміння високо поціновували сучасники, коментатори та поети минулого. 3 іншого боку, навіть славетне звання однієї із «чотирьох великих поетес династії Сун у жанрі ци» (“宋代四大女詞人”) 1 не врятувало У Шуцзі

1 Разом з У Шуцзі до «Чотирьох великих поетес династії Сун у жанрі ци» відносять Лі Цінчжао (李清照, 1084-1155? pp.), Чжу Шучжень (朱淑真, 1135-1180 рр.) та Чжан Юйнян (張玉娘, 1250-1277 pp.). 
(吳淑姬, прибл. 1185? р.) від майже-забуття: до нашого часу дійшло лише три або чотири іiі ци, а залишені свідчення про іiі життя викликають низку питань протягом багатьох століть. Переклад та детальний аналіз ци дозволить не лише ввести в науковий обіг української синології досі невідомі зразки сунської жіночої поезії, а і зробити припущення шодо авторства цих творів на підставі виокремлення традиційних і новаторських елементів у ії доробку.

Огляд наявної літератури засвідчує, що більшість сучасних китайських досліджень, які присвячені У Шуцзі, являють собою невеличкі коментарі до ii творів [刘敬折, 诸葛忆兵 1999, 219-221, 241; 夏承奉 2008, 955-956, 1019-1020; 胡晓明 2016, 162-164]. У деяких дослідженнях жіночої поезії династії Сун У Шуцзі згадується поміж інших поетес, а рядки з ії ци представлені як ілюстрація такої поезії [高明泉 1992, 19; 谢穑 2010, 112; 王东 林 2018,147$]$. Сдину інформацію про У Шуцзі, що не викликає сумнівів у дослідників, ми отримуємо 3 «Антології ци [майстра] Хуа'аня» (“花庵詞 選》) сунського поета Хуан Шена (黃升, середина ХІІІ ст.), де наведено стислі відомості та ци восьми сунських поетес [花菴詞選巻十]. Спочатку автор згадує iï як дуже талановиту жінку, що виділяється 3-поміж інших своїми здібностями: «Серед жінок [вона] дотепна та розумна». Далі він вказує на досить велику кількість поезій, що вміщені в ії власну збірку: «[Вона] має [збірку] ци у п'ять цзюанів під назвою «Теплою весною [тане] білий сніг»»». Наприкінці він дає власну оцінку її ци, порівнює їх із творами видатної китайської поетеси Лі Цінчжао (李清照, 1084-1155? pp.): «За красою [вони] не поступаються [ци] Лі Їань».

Загалом роботам, присвяченим дослідженню поезії У Шуцзі, бракує цілісного підходу до аналізу ци, оскільки дослідники розглядають окремі образи, прийоми чи рядки з її творів, залишаючи поза увагою специфічні особливості жанру ци. Що стосується досліджень поза межами Китаю, то таких немає, оскільки європейськими мовами твори У Шуцзі не перекладалися та не аналізувалися. Показовим винятком $\epsilon$ невеличкий біографічний огляд англійською мовою $з$ перекладами трьох ци [Li 2014, 461-462].

Головною проблемою історіографічної спадщини У Шуцзі є проблема іiі «роздвоєння» [邓红梅 2000, 137], а саме думка про те, що існували дві жінки на одне ім'я: одна жила за часів династії Північної Сун [唐圭璋 1965, 1354], а інша - за часів династії Південної Сун [唐圭璋 1965, 1041].

За першою версією, У Шуцзі походила 3 півночі країни [Li 2014, 461]. За «Реєстром округа Хучжоу» (“湖州府誌著錄”), вона народилася в місті Хучжоу [胡文楷 1985, 47]. Дівчина «добре зналася на музиці [й] поезії», а у складанні ци «була не гіршою за Лі Їань» [湖州府志]. У «Різноманітних записах із Кабінету чесності» (“誠齊雜記”, 1346 р.) юаньський літератор Лінь Кунь (林坤) наводить історію про молодість поетеси й особливості її одруження. Однак деякі сучасні дослідники вказують, що ця інформація «уважається сумнівною» [Li 2014, 461]. Так, «у [повіті] Феньїнь [була] жінка [на ім'я] У Шуцзі, [яка] не [встигла] одружитися, [оскільки іiі] наречений помер. Коли [він] ще був живий, [вона] вранці радісно вмивала лице, [iі] нефритова шпилька впала на землю і зламалася, й невдовзі [ії майбутній] чоловік помер. Її батько збирався знов видати [дочку] заміж. Дівчина заприсяглася: «[Коли] нефритова шпилька знов стане цілою, [лише] тоді вийду заміж». Минуло багато часу, [вона раптом] 
побачила ши, [написані] вченим [на ім'я] Ян Цзичжи, [та іiі] серце затремтіло. Відкривши шкатулку, [вона] побачила, [що ііi] шпилька ціла. Після цього вони одружилися» [胡文楷 1985,47 ].

Більше нічого не відомо про те, як склалося ії подружнє життя, був шлюб вдалим чи ні тощо 2 . Проте згадка про повіт Феньїнь (汾陰) $є$ вказівкою на північ Китаю, що дозволяє співвіднести цю історію з ім'ям «північної» У Шуцзі.

За другою версією, У Шуцзі була донькою дрібного збіднілого чиновника 3 півдня країни [Li 2014, 461]. Дівчина була гарною та розумною, вміла писати ши та ци [王兆鹏, 刘尊明 2003, 464]. Щоб поліпшити фінансовий стан своєї родини, вона зустрічалася із заможним чоловіком, через що ії звинуватили в розпусті [Li 2014, 461]. Начальник округу Ван Шипен (王十朋, 1112-1171 рр.) $)^{3}$ відправив У Шуцзі до в’язниці [王兆鹏, 刘尊明 2003, 465]. Деякі джерела вказують, що було подано скаргу на розгляд судді, який був настільки вражений розумом, чемністю та вправністю дівчини в написанні поезії, що наказав їі звільнити [Li 2014, 461]. Але інші джерела спираються на історію, яку наводить сучасник поетеси - видатний учений та письменник династії Південної Сун Хун Май (洪邁, 1123-1202 pр.). За його словами, після арешту У Шуцзі «покірно прийняла покарання та була засуджена до позбавлення волі. Чиновники з округу прибули до установи з виконання покарань. Як завжди, було виставлено вино та частування, настрій був чудовий у всіх присутніх. Потім оголосили, [що когось 3 арештантів] звільнять від кайданів [та дозволять] висловитися [під час] бенкету, [а саме] у наказі йшлося: «[Якщо] побачимо, [що] ти зможеш [скласти] ци та доречно в ньому уславити себе, тоді начальник округу тебе звільнить. Інакше - смерть». Дівчина відразу ж попросила [надати їй] тему [для ци]. [Оскільки був] кінець зими, сніг танув, незабаром [була] весна, обрали саме цей пейзаж для написання [ци у формі] лін [на мелодію] «Вічна туга у розлуці». [Дівчина] схопила пензля та зразу ж написала [ци]. <...> Усі присутні були в захваті [та] дуже задоволені. Наступного дня було надано клопотання пану Вану, де йшлося про їі справу. Ван зовсім не підозрював, [що] на неї звели наклеп, [та] зразу ж наказав [iіi] відпустити. Після цього ніхто не хотів 3 нею одружуватися. Син помічника міністра Чжоу ${ }^{4}$ купив $\dddot{1 і ̈ ~ т а ~ з р о б и в ~ н а л о ж н и ц е ю, ~ з в а л и ~ i i ̈ ~ Ш у ц з і » ~}$ [洪邁 1981, 1216].

Слова Хун Мая - сучасника поетеси - загострюють ситуацію 3 ідентифікацією особистості У Шуцзі. По-перше, він зазначає, що дівчина була з Хучжоу [洪邁 1981, 1216], тобто 3 того ж міста, як і «північна» У Шуцзі [胡文 楷 1985,47$]$, проте цю історію традиційно використовують саме для ілюстрації життя «південної» У Шуцзі. По-друге, він згадує ци поетеси на мелодію «Вічна туга у розлуці. [Форма] лін» (“長相思令”), завдяки феноменальному написанню якого вона уникла ув'язнення та, можливо, страти. За іншими ж джерелами, автором цього ци є У Шуцзі з Північної Сун [唐圭璋 1965, 1354].

2 У деяких сучасних дослідженнях вказується інше ім’я іiі чоловіка - Ян Шичжи (楊士 治) [邓红梅 2000, 137].

3 Ван Шипен став начальником округу в 1167 p. [王兆鹏, 刘尊明 2003, 465], що дозволяє датувати життя У Шуцзі другою половиною XII ст.

4 У деяких роботах вказується лише прізвище чоловіка Чжоу без якихось інших деталей [Li 2014, 461]. 
Ще більше питань щодо особистості У Шуцзі та ії біографії додають слова південносунського літератора Хуан Шена, точніше їх відсутність. У своїй антології він неодмінно зазначає те, чиєю дружиною або наложницею була кожна з наведених поетес, проте зовсім ігнорує це, коли йдеться про У Шуцзі. На думку деяких дослідників, це і може свідчити на користь гіпотези про існування двох різних жінок з однаковим ім'ям: ніде ніколи не вказувалось повне ім'я чоловіка «південної» У Шуцзі, лише згадувалось його прізвище. Тому можна припустити, що на момент написання Хуан Шеном свого твору (XIII ст.) воно вже загубилося, а згадка в більш пізніх джерелах (XIV ст.) повного імені іншого чоловіка (Ян Цзичжи, 楊子治) є саме свідченням того, що ідеться про іншу жінку - «південну» У Шуцзі [任日鎬 1984, 35].

Невизначеність з особистістю поетеси призводить до того, що сучасні дослідники й упорядники антологій вказують різну кількість творів за авторством У Шуцзі: один [陶尔夫, 刘敬圻 1994, 248], три [唐宋词鉴赏辞典 2001, 1254] або чотири ци [邓红梅 2000, 137]. Підставою для цього є не сумніви в авторстві того чи іншого ци, а саме неможливість чітко ідентифікувати кількість авторів на ім'я У Шуцзі, установити кількість ци, що належить кожній 3 них. Іноді упорядники вміщують усі твори, проте зазначають, що авторками $\epsilon$ дві різні поетеси ${ }^{5}$.

Головною метою статті є обгрунтування засобами літературознавчого дослідження думки про існування двох поетес з однаковим прізвищем - У Шуцзі. Цієї мети я планую досягти завдяки аналізу чотирьох ци, відправним пунктом якого $є$ розмежування традиційного та новаторського у класичній китайській поезії. Зокрема, під традицією я розумію відповідність створеного автором ци «стандартній формі» чженті (正體) 6 . Це означатиме наявність, 3 одного боку, взірця для наслідування тематики, просодії, композиції, образів, прийомів тощо, з іншого боку - великої кількості творів, складених за цим взірцем. Відповідно новаторство визначається як відхід від панівних взірців віршування й утворення нових, раніше небачених прикладів. Отже, я стверджую, що перші три ци є традиційними у вказаному вище сенсі, тоді як четвертий ци є новаторським. Це дає мені підстави стверджувати, що вони були написані різними поетесами.

Емпіричним матеріалом є чотири ци, що приписуються У Шуцзі, які я розділила на дві групи: традиційні та новаторські. До першої групи я

5 Так, у найавторитетнішій антології «Повне зібрання сунських ци» (“全宋詞»), де представлено понад 21 тисячу поезій, У Шуцзі з Північної Сун вказана авторкою ци на мелодію «Вічна туга у розлуці. [Форма] лін» (“長相思令”) [唐圭璋 1965,1354 ], а У Шуцзі 3 Південної Сун зазначена авторкою трьох ци на мелодії «Маленькі пагорби» (“小重山”), «Шкодую про розставання» (“惜分飛”), «Чжу Їнтай. [Форма] цзінь» (“祝英台近”) і одного рядка із ци на втрачену мелодію [唐圭璋1965, 1041]. Проте зазначено, що в першому випадку укладач зробив помилку, коли вказав, що авторка походить із Північної Сун [唐圭 璋 1965,1354$]$. Однак не надано жодних роз'яснень. У деяких виданнях наведен абсолютно протилежний розподіл творів за авторством: У Шуцзі з Північної Сун належить три ци [刘敬圻, 诸葛忆兵 1999, 219-221], тоді як У Шуцзі з Південної Сун зазначена авторкою одного ци [刘敬圻, 诸葛忆兵 1999, 241].

6 Розрізнюються «стандартна форма», або чженті (正體), та «змінена форма», або бяньті (變體). Чженті ставав або перший ци на цю мелодію, або найпопулярніша схема для ци на цю мелодію [夏承奉, 吴熊和 2016,48 ]. Бяньті - це всі інші варіанти, відмінні від чженті [吴丈蜀 2016, 52]. 
віднесла три ци, які було створено на популярні за часів династії Сун мелодії ${ }^{7}$.

Ци на мелодію «Чжу Їнтай. [Форма] цзінь» (“祝英台近”):

粉痕銷, [Від] пудри сліду не залишилося,

芳信㫁, Ароматні листи перестала [отримувати],

好夢又無據。Хороші сни знов не приходять [до мене].

病酒無聊, [Через ией] біль [n'ю] вино, [але] нерадісно[мені],

攲枕聽春雨。 Лежу на подушці, слухаючи весняний дощ.

斷腸曲曲屏山， Рвуться нутрощі, [коли дивлюсь на] вигини ширми

溫溫沈水, [Та на] ніжний-ніжний [димок] ченьшуй,

都是舊、看承人處。 Все [як] раніше тут, [де] ти дбав [про мене].

久離阻。Довгий час [ми] у розлуці.

應念一點芳心， Маєш зрозуміти краплину [мого] ароматного серця.

閒愁知幾許。 Безпорадну тугу [мені] знати [ще] скільки?

偷照菱花， Крадькома побачила [себе] [в] квітці водяного горіха,

清瘦自羞覰。 Схудла [так, що] соромно дивитися.

可堪梅子酸時, Як можна витримати сезон «Кислої мей»,

楊花飛絮， [Коли 3] тополі летить пух,

亂鶯鬧、催將春去。Метушаться вивільги галасливі, кваплячи весни кінець?

Ця мелодія також трапляється під іншими назвами, зокрема: «Чжу Їнтай» (“祝英台”), «Чжу Їнтай. [Форма] лін» (“祝英台令”), «Дорогоцінна шпилька зламалась» (“寶釷分”), «Під місяцем пишу музику [для] сяо» (“月底修簫譜”), «Щебет ластівок [i] вивільг» (“燕鶯語”), «Ци [до свята] Ханьши» (“寒食詞”) [杨文生 1981, 107; 王兆鹏, 刘尊明 2003, 262]. Назва мелодії обумовлює й тематику більшості ци, що писалися на неї, оскільки вона є посиланням на відому легенду про трагічне кохання Лян Шаньбо (梁山伯) i Чжу Їнтай (祝英台), які змогли бути разом лише після смерті, перетворившись на метеликів.

Найпершим твором на цю мелодію вважається ци видатного сунського поета Су Ши (蘇軾, 1037-1101) [王兆鹏, 刘尊明 2003, 262], проте «стандартною формою» виступає ци поета династії Південної Сун Чен Хе (程核, XII ст.) [黄华童, 蔡国强 2019, 297]. Згідно з нею ци складається із 77 ієрогліфів, які поділені на дві строфи, вісім рядків у кожній. Римуються ієрогліфи під тоном цзе ${ }^{8}:$ у першій строфі три рими, у другій - чотири ${ }^{9}$ [黄华童, 蔡国强 2019,298 ]. Окрім чженті, існує щонайменш сім «змінених форм» бяньті [王兆鹏, 刘尊明 2003, 262].

Ци на мелодію «Маленькі пагорби» (“小重山”):

謝了茶蔴春事休。 Зів’яла тумі, весна добігає кінця.

無多花片子，綴枝頭。Небагато [у] квітів пелюсток，

7 Із ци, що були написані на ці мелодії за часів династії Сун, збереглося 79 ци на мелодію «Чжу Їнтай. [Форма] цзінь» (“祝英台近”), 115 ци на мелодію «Маленькі пагорби» (“小重山”) та 32 ци на мелодію «Шкодую про розставання» (“惜分飛”) [词牌。历代作品].

8 Три тони шан (上聲), цюй (去聲) та жу (入聲) разом утворюють тон цзе (人聲). У статті всі подальші визначення типів рим та їхня приналежність до певної групи відповідають розподілу, наведеному в «Новому виданні рим із Піншуя» (“平水新刊韻略», 1229 р.) Ван Веньюя (王文鬱), де відображено норми читання середньокитайської мови [平水韵].

9 Деякі джерела зазначають, що в обох строфах по чотири рими [王兆鹏, 刘尊明 $2003,262]$. 
[щол] прикрашають верхівки гілок.

庭槐影碎被風揉， [Ha] дворі тінь софори розірвана на шматки, вітром зім'ята [краса].

鶯雖老, 聲尚帶嬌羞。Вивільга хоч й постарішала,

[iï] спів все щзе чарівно-сором'язливий.

獨自倚妝樓。Самотньо притулюся до прикрашеної вежі.

一川煙草浪, 祱雲浮。[Ha] річці туман, трава [мов] хвилі;

схилившись, хмари пливуть.

不如歸去下簾鉤。 Краще повернусь [до кімнати та]

спущу штори з гачків.

心兒小, 難著許多愁。Серце [в мене] маленьке,

важко вмістити [йому] багато туги.

Мелодія «Маленькі пагорби» (“小重山”) для ци вперше була використана видатним танським поетом Вей Чжуаном (韋莊, 836-910) [王兆鹏, 刘尊明 2003, 100]. Згідно із чженті для цієї мелодії ци має обсяг у 58 ієрогліфів, що поділяються на дві строфи по чотири рядки, кожен із яких римується під тоном пін [王兆鹏, 刘尊明 2003, 100]. Тематика більшості танських ци на цю мелодію була пов'язана з описом почуттів туги та смутку жінок в імператорському палаці (“宮怨”) [杨文生 1981, 77]. Поділ на дві строфи за традицією зумовлював їхнє тематичне протиставлення: перша строфа зображувала природу чи пейзаж зовні, а друга - почуття чи думки ліричної героїні [夏承奉, 吴熊和 2016, 93-94].

Ци на мелодію «Шкодую про розставання» (“惜分飛”):

岸柳依依拖金縷。[Hа] березі верба ніжна-тендітна,

звисають [iі] золоті нитки.

是我朝來別處。Отже, я вранці прийшла [до] місця,

[де ми] розстанемося.

唯有多情絮, Лише сповнений почуттів пух [верби],

故來衣上留人住。Навмисно за одяг чіпляється,

[благаючи] тебе зупинитися.

兩眼啼紅空彈與, [3] обох очей [ллються] сльози червоні,

марно грала [на ціні],

未見桃花又去。Не побачив квіти персика, знов поїхав.

一片征帆舉, Один парус, [що] попливе вдалечінь, підняв,

斷腸遙指苔溪路。Рвуться нутрощі,

[коли] здалеку вказав на дорогу [вдовж] Тяосі.

Ця мелодія також трапляється під трьома іншими назвами: «Співчуваю [закоханій] парі» (“惜雙雙”), «Співчуваю [закоханій] парі. [Форма] лін» (“惜雙 雙令”) та 《Жалію аромат квітів» (“惜芳菲”) [王兆鹏, 刘尊明 2003, 314], що зумовлює різну довжину ци (від 50 до 56 ієрогліфів) та відмінний розподіл на рядки та строфи.

Згідно із чженті, основою для якої став твір сунського поета Мао Пана (毛滂, 1056-1124), ци на цю мелодію складається 350 ієрогліфів та має дві строфи по чотири рядки, кожен із яких римується під тоном цзе [王兆鹏, 刘尊明 2003, 314]. Тематика та зміст ци Мао Пана цілком відповідають назві мелодії: його ци присвячено зображенню туги закоханих у розлуці та, зокрема, душевних страждань ліричної героїні. За композиційною побудовою, строфи 
в ци Мао Пана протиставлені за часом: перша строфа присвячена опису подій перед розставанням, а друга - зображенню почуттів героїні після розлуки.

Аналіз тематики, просодії, композиційної побудови, образів та художніх прийомів вищенаведених поезій дозволяє віднести їх до групи традиційних ци. Зокрема, тематично всі наведені вище ци У Шуцзі присвячені опису туги жінки в розлуці з коханим. Зображені події відбуваються протягом одного дня наприкінці весни й обмежені кімнатою жінки чи будинком із садом, де вона мешкає, або берегом річки, де вона попрощалась з коханим. Наявні невеликі зміни $з$ боку просодії, зокрема кількості рим ${ }^{10}$, зміни в чергуванні тонів ${ }^{11}$ та урізноманітнення тонів у межах рими ${ }^{12}$, проте ці трансформації загалом не порушують чженті, додаючи лише виразності та ритмічності цим рядкам ${ }^{13}$. За композиційною побудовою всі три ци відповідають чженті, маючи відповідні тематичні протиставлення в обох строфах.

Використані в них образи та художні прийоми також можна вважати гарним зразком наслідування поетичної традиції. Так, поетеса звертається до класичних весняних образів (дощ, сезон «Кислої мей», пух 3 тополі, спів вивільги, верба, квіти персика, трава, хмари, що пливуть високо в небі тощо), які зазвичай $є$ ознаками весни в поетичних творах та використовуються для контрастного зображення печалі та суму ліричної героїні. Що стосується художніх прийомів, то У Шуцзі тричі застосовує традиційний для китайської

${ }^{10}$ У ци У Шуцзі на мелодію «Чжу Їнтай. [Форма] цзінь» (“祝英台近”) у першій строфі три рими, у другій - п’ять. Хоча у двох «змінених формах» $є$ такий же розподіл рим між строфами, однак ци У Шуцзі не відповідає їм за схемою чергування тонів у рядках, тому не можна віднести його до бяньті.

11 У ци У Шуцзі на мелодію «Шкодую про розставання» (“惜分飛”) замість тону цзе для шостого ієрогліфа в першому рядку кожної строфи вона використовує тон пін.

12 У ци на мелодію «Шкодую про розставання» (“惜分飛”), не порушуючи вимогу чженті щодо рими під тоном цзе, У Шуцзі дещо урізноманітнює іiі, роблячи римування більш складним та вишуканим, ніж в оригінальному ци Мао Пана, де всі рими під тоном цюй належать до однієї групи (七遇). Однак у кожній строфі ци У Шуцзі використано по дві рими під тоном шан та цюй, які поєднуються одна з одною в певному порядку: 上 上去去 в першій строфі та 上去上去 у другій строфі. Водночас поетеса обирає чотири групи рим (1. 七㬍, 2.六語, 3.六禦та 4. 七遇), використання яких у певному порядку зв'язує строфи одну з одною. Порівняння із чженті схематично можна зобразити так:

\begin{tabular}{|l|l|}
\hline Схема римування у чженті (ци Мао Пана) & Схема римування в ци У Шуцзі \\
\hline 1 строфа: $1-1$ & 1 строфа: $1-2$ \\
2 строфа: $1-1$ & 2 строфа: 2 \\
\hline
\end{tabular}

Як бачимо, у ци У Шуцзі винятком є лише перший рядок першої строфи, який не має відповідної рими зі своєї групи у другій строфі, усі інші рядки тісно пов'язані не лише римами під тоном шан та цюй, а також римуванням у межах певної групи рим. У чженті не має такого розмаїття рим, що робить його більш монотонним.

13 Сунські літератори не лише вказували на важливість «уміння використовувати тон цюй у рядках» [夏承奉, 吴熊和 2016, 63], а й відзначали його роль у ци: коли під час зміни рими використовується тон цюй, то це зроблено автором для посилення ефекту [夏承奉, 吴熊和 2016,65 ]. Окрім того, вдале поєднання тону цюй із тоном шан, особливо під час їх римування, «допоможе ритмічності» твору [夏承奉, 吴熊和 2016, 64]. Пов’язано це 3 тим що «тон шан - неквапливий і м'який, його тональність низька; тон цюй - різкий та сильний, його тональність висока; їх використання разом можливе лише під час руху мелодії вгору і вниз» [夏承奉, 吴熊和 2016, 64]. У даному разі У Шуцзі чотири рази використовує риму під тоном цюй, додаючи емоційності саме в тих рядках, де йдеться про почуття ліричної героїні напередодні та після розлуки з коханим. 
поезії прийом алюзій: двічі це згадка про те, що «рвуться нутрощі» (“逆腸”) ${ }^{14}$, один раз вказівка на «сльози червоні» (“啼紅”) ${ }^{15}$. За традицією У Шуцзі використовує ці алюзії для ілюстрації ступеня душевних мук і страждань ліричної героїні, її переживань та туги за коханим.

На відміну від цих трьох творів, написаних у руслі традиції, наступний ци на мелодію «Вічна туга у розлуці. [Форма] лін» (“長相思令”) ${ }^{16}$, який начебто врятував У Шуцзі від ув'язнення та подальшої страти, є абсолютно новаторським:

煙霏霏, Туман клубочиться, кружелиться,

雪霏霏。Сніг падає, хурделиться.

雪向梅花枝上堆, Сніг на гілки мейхуа горами [впада],

春從何處回? Весна звідки повернеться?

醉眼開, Хмільні очі відкрила,

睡眼開, Заспані очі розплющила,

疏影横斜安在哉? Розсіяні тіні падають навскіс, де ж [вона]?

從教塞管催。Дозволю сайгуань поквапити [ii]].

Назва цієї мелодії разом з іншими варіантами ${ }^{17}$ походить від мелодії «Вічна туга у розлуці» (“長相思”), створеної за часів династії Тан у стінах Придворної школи акторів, співаків та музикантів (教坊) [王兆鹏, 刘尊明 2003, 111]. Оскільки ци Бо Цзюй-ї (白居易, 772-846 рр.) довжиною у 36 ієрогліфів був першим твором, написаним на цю мелодію, саме він уважається чженті. Тематично його ци не вирізняється 3-поміж більшості танських ци, які були присвячені опису тужливих почуттів жінки в очікуванні повернення свого чоловіка. За композицією він також має традиційну побудову: перша строфа описує пейзаж, друга строфа передає почуття ліричної героїні. Кожна строфа складається із чотирьох рядків, які мають певну специфіку в римуванні: три рими під тоном пін і один повтор рими або дєюнь (疊韻) [舒梦兰 2001, 10].

14 Її витоки вбачають в розповіді Лю Їціна (劉義慶, 403-444рр.) зі збірки «Нове викладення оповідань, що у світі ходять» (“世說新語”). Зокрема там говориться, що «коли гун Хуань [Вень] прибув у Шу і дістався Трьох ущелин, хтось із солдатів спіймав дитинча мавпи. Його мати, тримаючись уздовж берега і жалібно плачучи, невтомно бігла за ними більше 100 лі. Зрештою, вона стрибнула в човен, і померла. Коли ж розкрили ії черевну порожнину, то побачили, що кожен цунь ії кишок було розірвано. Гун, почувши це, був розлючений, і наказав вигнати цього солдата [3 армії]» [陈祖美 2003, 227].

15 Ця алюзія пов'язана з відомою історією часів Саньго (三國, 220-280 pp.), натяк на яку вказує на ступінь туги героїні за коханим. Згідно із «Записами про забуті події» (“拾 遺記”) Ван Цзя (王嘉, IV ст.) відома красуня Сюе Лін’юнь (薛靈芸), яка була улюбленою наложницею імператора династії Вей (曹魏, 220-226рр.) Цао Пі (曹丕, 187-226 рр.), після прощання з батьками весь шлях до палацу гірко плакала, не зупиняючись. Її туга за батьками та рідною домівкою була настільки великою, що сльози, які вона весь цей час збирала в нефритовий сосуд, перетворилися на кров [胡晓明 2016, 164]. Відтоді «червоні сльози» (“紅淚”), або «криваві сльози» (“血淚”) набувають значення великої туги красивої жінки.

16 Як і три попередні мелодії, ця мелодія теж була досить популярною за часів династії Сун: збереглося 110 ци, написаних на неї [词牌。历代作品]. Отже, з одного боку, завдання, що постало перед У Шуцзі, не було складним, оскільки ця мелодія була досить відомою, але, з іншого боку, труднощі полягали саме в тому, як за допомогою всього традиційного та відомого зробити щось настільки нове й досі небачене, щоб вразити присутніх.

17 «Гора У зеленіє» (“呂山青”), «Гори потроху зеленіють» (“山漸青”), «[У] зелених горах один одного проводжаємо [та] зустрічаємо» (“青山相送迎”), «Туга в розлуці. [Форма] лін» (“相思令”) [黄华童, 蔡国强 2019, 11]. 
Порівняно із чженті в ци У Шуцзі наявні значні трансформації, зокрема в тематиці, римуванні, чергуванні тонів, використанні повторів і алітерацій, що не лише увиразнюють його мелодику, а й роблять вірш більш витонченим та багатоплановим.

Згідно з історією написання цього ци, утілення обраної теми було однією 3 умов вдалого виконання завдання («[оскільки був] кінець зими, сніг танув, незабаром [була] весна, обрали саме цей пейзаж для написання» [洪邁 1981, 1216]). Проте, на відміну від конвенціональної теми зображення туги жінки в розлуці із чоловіком, У Шуцзі в рамках одного ци створює два різнопланові твори: перший «зовнішній» пласт являє собою пейзажну замальовку, другий «внутрішній» пласт - приховане викладення подій, що безпосередньо вплинули на долю поетеси та стали причиною написання цього ци.

Уже $з$ перших рядків спостерігаються деякі невідповідності між зазначеною тематикою та тим, що зображено. У Шуцзі в описі пейзажу на початку весни, коли тане сніг, зазначає: “煙霏霏, 雪霏霏” (Туман клубочиться, кружелиться, Сніг падає, хурделиться), а в наступному рядку ще й підкреслює силу цього снігопаду: “雪向梅花枝上堆” (Сніг на гілки мейхуа горами [впада]). Китайські дослідники зазначають, що це не якась необачність поетеси чи гіперболізація: у цих рядках У Шуцзі вдається метафорично описати те, як була сфабрикована iii справа, під яким страшенним тиском була вона під час суду [夏承奉 2008, 1020]. Образ весни, що з’являється в наступному рядку: “春從何處回?” (Весна звідки повернеться?), є уособленням начальника округу та справедливого розгляду іiі справи. Отже, перша строфа є майстерним прикладом поєднання декількох смислових пластів, коли через зображення пейзажу поетеса змогла висловити своє власне ставлення до розгляду справи, порушеної проти неї, та натякнути на це високоповажним чиновникам.

Друга строфа також має декілька смислових пластів та, відповідно, різні інтерпретації. По-перше, iii можна потрактувати як подальший опис пейзажу довкола, коли зображується прокидання мейхуа, що розплющує свої очі, тобто відкриває бутони. По-друге, згадка про хмільні та заспані очі може бути не справжнім описом зовнішності ліричної героїні, а знову ж метафорою ії душевного та фізичного стану, коли в результаті судового процесу вона приголомшена, дезорієнтована та відчуває розгубленість (暈頭轉向) [夏承奉 2008, 1020]. Третій рядок - “疏影橫斜安在哉?” (Розсіяні тіні падають навскіс, де ж [вона]?) - тісно пов'язаний із двома попередніми та вказує на довготривалість судового процесу, через що жінка не побачила цвітіння мейхуа та не змогла помилуватися цією красою.

В останньому рядку згадується сайгуань (塞管), що є іншою назвою для цянської дудки ${ }^{18}$, або цянді (㒸笛) [夏承奉 2008,1020 ], згадка про яку у класичній поезії завжди пов'язується із закінченням періоду цвітіння мейхуа та сумом $^{19}$. Завдяки цьому останній рядок можна також інтерпретувати по-різному: або як кінець весняної пейзажної замальовки, або як вмовляння чиновників

\footnotetext{
${ }^{18}$ Цян (芫), або тангути, - народність, відома з найдавніших часів і до падіння їхньої держави Сіся (西夏) у XIII ст.

19 Така асоціація невипадкова, бо традиційно вважалося, що «музика наскільки засмутила квіти [мей], що вони зів'яли» [Рannam 2009, 115]. Окрім того, серед мелодій для цянді $є$ одна під назвою «Мейхуа опадає» (“梅花落”) [柯宝成 2009, 50].
} 
покінчити із судовою справою, оскільки героїня вже не витримує цього напруження.

Що стосується змін у просодії, то передусім вони стосуються римування та чергування тонів пін і цзе. Хоча поетеса також використовує риму під тоном пін у кожному рядку, проте, на відміну від чженті ${ }^{20}$, вона належить до двох різних груп (五微 та 十灰), що урізноманітнює римування ${ }^{21}$. Чергування тонів зазнає більш радикальних трансформацій. По-перше, поетеса змінює порядок чергування тонів у строфах, передбачений схемою для цієї мелодії [黄华童, 蔡 国强 2019, 11]: чергування тонів для першої строфи вона використовує у другій строфі, а чергування тонів для другої строфи, навпаки, у першій. По-друге, вона тричі кардинально змінює тони ієрогліфів, зазначені у схемі: один раз змінює тон пін на цзе, двічі - тон цзе на пін.

У ци У Шуцзі наявні також деякі зміни у вживанні повторів ієрогліфів порівняно із ци Бо Цзюй-ї та відповідно чженті: поет вдається до повторів шести різних ієрогліфів (загалом повторюється 15 ієрогліфів) 22, а поетеса повторює п'ять ієрогліфів (12 ієрогліфів) ${ }^{23}$. В обох випадках є прості повтори та повтори рими дєюнь. Однак цікавим $є$ не просто факт наявності повторів, а саме те, як вони використані: поетеса змінює місцями першу та другу строфу, як і в чергуванні тонів. Якщо порівняти першу строфу ци Бо Цзюй-ї із другою строфою ци У Шуцзі, то можна побачити майже однакову схему використання повторів у перших трьох рядках ${ }^{24}$. Анадиплозис, використаний у другому та третьому рядках Бо Цзюй-ї, зникає в ци У Шуцзі, але зберігається епіфора.

\begin{tabular}{|c|c|c|c|}
\hline \multicolumn{2}{|c|}{ Перша строфа ци Бо Цзюй-ї } & \multicolumn{2}{|c|}{ Друга строфа ци У Шуцзі } \\
\hline текст & схема & текст & схема \\
\hline $\begin{array}{l}\text { 泣水流, } \\
\text { 泗水流, } \\
\text { 流到瓜州古渡頭。 }\end{array}$ & $\begin{array}{l}\cdot 12 \\
\cdot 12 \\
2 \ldots \ldots\end{array}$ & $\begin{array}{l}\text { 醉眼開, } \\
\text { 睡眼開, } \\
\text { 疏影横斜安在哉? }\end{array}$ & $\begin{array}{r}\cdot 12 \\
\cdot 12\end{array}$ \\
\hline
\end{tabular}

Абсолютно ідентична схема повторів спостерігається під час порівняння другої строфи ци Бо Цзюй-ї з першою строфою ци У Шуцзі. У даному разі поетеса зберігає й анафору, і епіфору в суміжних рядках:

${ }^{20}$ Усі рими в ци Бо Цзюй-ї належать до однієї групи рим (十一尤).

${ }^{21}$ Варто зазначити, що «до династії Цін не було спеціальних досліджень із рими, на які можна було б спиратися, тому поети брали за взірець використання рими у творах попередників» [吴丈䖿 2016, 81]. Однак із часу написання ци Бо Цзюй-ї та до моменту створення ци У Шуцзі минуло більше трьох століть, що, безперечно, позначилося на правилах написання творів у цьому жанрі. Зміни з боку використання рими є також у ци інших поетів [黄华童, 蔡国强 2019, 11], але, по-перше, кількість таких творів дуже мала, по-друге, усі випадки трансформацій стосуються лише подвоєння рими, а не зміни тонів.

${ }_{22}$ Так, у його ци ієрогліф 水 повторюється двічі, 流 - тричі (двічі просте повторення, раз - дєюнь), 到 - двічі, 點 - двічі, 悠 - 4 рази (тричі просте повторення, раз - дєюнь), 恨 двічі.

${ }^{23}$ Поетеса повторює ієрогліф 霏 4 рази (тричі просте повторення, раз - дєюнь), 雪 двічі, 從 - двічі, 眼- двічі, 开- двічі (раз просте вживання, раз - дєюнь).

${ }^{24}$ Ієрогліфи, що не повторюються в межах строфи, позначені $(\cdot)$, повтори ієрогліфів позначені цифрами, кожна з яких вказує на окремий ієрогліф. 


\begin{tabular}{|c|c|c|c|}
\hline \multicolumn{2}{|c|}{ Друга строфа ци Бо Цзюй-ї } & \multicolumn{2}{|c|}{ Перша строфа ци У Шуцзі } \\
\hline текст & схема & текст & схема \\
\hline $\begin{array}{l}\text { 思悠悠, } \\
\text { 恨悠悠, } \\
\text { 恨到歸時方始休。 }\end{array}$ & $\begin{array}{lll}\cdot & 3 & 3 \\
4 & 3 & 3 \\
4 & \cdots & \cdots\end{array}$ & $\begin{array}{l}\text { 煙霏霏, } \\
\text { 雪霏霏。 } \\
\text { 雪向梅花枝上堆。 }\end{array}$ & $\begin{array}{lll}\cdot & 3 & 3 \\
4 & 3 & 3 \\
4 & \cdots & \cdots\end{array}$ \\
\hline
\end{tabular}

Окрім цього, також варто звернути увагу на те, що обидва поети майстерно обіграють повтори ще й на ієрогліфічному рівні. Бо Цзюй-ї використовує 7 ієрогліфів із детермінативом «вода» (У ) та двічі повторює сам ієрогліф «вода» / «ріка» (水), а також 8 ієрогліфів із детермінативом «серце» (心 / 小 ); У Шуцзі використовує 6 ієрогліфів із детермінативом «дощ» (雨), 3 ієрогліфи $з$ детермінативом «дерево» (木) та 3 ієрогліфи $з$ детермінативом «око» (目).

Починаючи із «Шицзіна» (“詩經”) у китайській поезії дуже важливу роль відігравали також різні типи алітерацій, зокрема «парні приголосні» (雙聲) i «голосні, що накладаються» (疊韻) [Китайская поэзия... 2007, 20]. У цьому ци У Шуцзі також спостерігається досить високий коефіцієнт фонічної організації, представлений цими двома видами алітерацій ${ }^{25}$, що не є характерним для вищерозглянутих творів та чженті на цю мелодію ${ }^{26}$.

За композиційною побудовою ци У Шуцзі також значно відрізняється від чженті. Навіть якщо розглядати його як пейзажну замальовку, не враховуючи прихованого змісту, то у другій строфі відсутнє зображення почуттів ліричної героїні, а натомість продовжується опис мей та пейзажу навколо. Лише згадку про сайгуань можна вважати непрямою вказівкою на висловлювання печалі.

На відміну від чженті ${ }^{27}$, кількість образів у ци У Шуцзі зведено до мінімуму: туман (煙), сніг (雪), мейхуа (梅花) та сайгуань (塞管), що не перевантажує твір та дозволяє зосередитися саме на них. Що стосується художніх прийомів, то тут поетеса також використовує алюзію, але, на відміну від попередніх трьох ци, це посилання на рядки із ши поета династії Північної Сун Лінь Бу (林逋, 967-1028 рр.) під назвою «У саду в горах маленька мей» (“山園小梅”) [夏承奉 2008, 1020]:

疏影橫斜水清淺, Розсіяні тіні падають навскіс, ріка прозора [та] мілка,

暗香浮動月黃昏。Тонкий аромат пливе, місяць [з'являється] у сутінках.

Таке посилання не на усталені образи III та V ст. (“啼紅” та “斷腸”), що постійно траплялися в поетичних творах відтоді та були банальними, а на маловідомі рядки поета династії Північної Сун не лише вказує на обізнаність поетеси та ії поетичні здібності, а й додає печальної тональності всьому ци: саме тут зосереджена ії туга через втрату можливості насолоджуватися гарними речами, чи то краса квітучої мей чи поетичний шедевр.

Висновки. Отже, ци У Шуцзі на мелодію «Вічна туга у розлуці. [Форма] лін» (“長相思令”) багато в чому порушує усталений взірець для написання та

${ }^{25}$ Наприклад: хие̌ xiàng; chūn cóng hé chù huí; zuìyăn kāi, shuìyăn kāi; shuìyăn - shū y̌̀ng; zài zāì.

26 Якщо не враховувати повтори ієрогліфів, то в ци Бо Цзюй-ї можна побачити лише такі алітерації: zhōu gǔdù tóu, guī shí fāngshĭ.

${ }^{27}$ Ци довжиною у 36 ієрогліфів Бо Цзюй-ї перенасичений образами: дві ріки (油水та 泗水), стара переправа в Гуачжоу (瓜州古渡頭), гора У (吳山), ясний місяць (月明), вежа (樓) та поруччя, на яке спирається героїня (倚). 
має велику кількість новаторських елементів. Він значно вирізняється як на тлі чженті, так і порівняно із трьома іншими ци, що належать У Шуцзі $з$ династії Північної Сун. Це дає підстави для висновку щодо його приналежності до доробку іншої поетеси - У Шуцзі з династії Південної Сун. У цій атрибуції я виходжу з того, що поетичний талант передбачає певний ступінь новаторства, що проявляється в усіх творах автора. Відповідно сумнівною видається думка, що та сама авторка створювала абсолютно непримітні та водночас унікально новаторські ци.

Моя позиція має щонайменш три вразливі моменти. По-перше, варто зважити на високий ступінь формалізації поезії в середньовічному Китаї, через що більшість ци писалася згідно із традицією, за визнаним каноном та шаблоном, тому твори багато в чому нагадували один одний. По-друге, є підстави вважати, що немає великих авторів, є лише великі твори. Відповідно, новаторство притаманне окремим віршам, а не всьому доробку поета. По-трете, дискусійним залишається питання не стільки про існування двох жінок з однаковим ім'ям, скільки про те, яку саме У Шуцзі вважали сучасники (імовірно, на підставі втрачених ци) однією із «чотирьох великих поетес династії Сун у жанрі ци». Розгляду цих питань я планую присвятити мої наступні публікації.

\section{ЛІТЕРАТУРА}

Li Guotong. Wu Shuji. Biographical dictionary of Chinese women: Tang Through Ming, 618-1644. Armonk, New York : M.E. Sharpe, 2014. P. 461-462.

Pannam C. Music from a jade flute. The $c i$ poems of Li Qingzhao. Melbourne : Hybrid Publishers, 2009.

Китайская поэзия в переводах Льва Меньшикова. Санкт-Петербург : Петербургское востоковедение, 2007.

陈祖美. 李清照词新释辑评. 北京: 中国书店, 2003.

词牌. 历代作品. URL: https://sou-yun.cn/QueryCiTune.aspx (дата звернення:

21.11.2021).

邓红梅. 女性词史. 济南: 山东教育出版社, 2000.

高明泉. 宋代女词人创作简述. 固原师专学报, 1992 年 4 期, 第 18-21页.

洪邁. 夷堅志 (全四册). 北京 : 中華書局出版, 1981.

胡文楷. 历代妇女著作考. 上海 : 上海古籍出版社, 1985 .

胡晓明. 历代女性诗词鉴赏辞典. 上海: 上海世纪出版股份有限公司, 2016.

湖州府志. URL: https://ctext.org/wiki.pl?if=gb\&chapter=978124\#p24 (дата звернення: 26.09.2021).

花菴詞選巻十. URL: https://ctext.org/wiki.pl?if=gb\&chapter=749601\#p48

(дата звернення: 26.09.2021).

黄华童, 蔡国强. 实用唐宋词谱. 北京 : 北京大学出版社, 2019.

柯宝成.李清照全集: 汇评本.武汉: 崇文书局,2009.

刘敬圻, 诸葛忆兵. 中国历代名家流派词传. 宋代女词人词传. 长春: 吉林人 民出版社, 1999.

平水韵. URL: https://sou-yun.cn/QR.aspx (дата звернення: 21.11.2021).

任日鎬. 宋代女詞人評述. 新北: 臺灣商務印書館, 1984.

舒梦兰. 白香词谱 (学词人门第一书). 上海 : 上海古籍出版社, 2001 .

唐圭璋. 全宋词.北京: 中华书局出版,1965.

唐宋词鉴赏辞典. 南宋, 辽, 金. 上海 :上海辞书出版社, 2001. 
陶尔夫, 刘敬圻. 南宋词史. 哈尔滨 : 黑龙江人民出版社, 1994.

王东林. 宋代女词人常用意象下的情感体验. 文学教育（上）, 2018 (12), 第 146-147 页.

王兆鹏, 刘尊明. 宋词大辞典. 南京 : 凤凰出版社, 2003.

吴丈蜀. 词学概说. 北京 : 中华书局, 2016.

夏承奉, 吴熊和. 读词常识. 北京 : 中华书局. 2016.

夏承奉. 宋词鉴赏辞典. 上册. 上海 : 上海辞书出版社, 2008.

谢穑. 宋代女性词人群体研究. 长沙 : 湖南人民出版社, 2010 .

杨文生. 词谱简编. 成都 : 四川人民出版社, 1981.

\section{REFERENCES}

Li Guotong (2014), "Wu Shuji". Biographical dictionary of Chinese women: Tang Through Ming, 618-1644. M.E. Sharpe, Armonk, New York, pp. 461-462.

Pannam C. (2009), Music from a jade flute. The ci poems of Li Qingzhao. Hybrid Publishers, Melbourne.

Kitayskaya poeziya v perevodakh L'va Men'shikova (2007), Peterburgskoye Vostokovedeniye, Sankt-Peterburg. (In Russian).

Chen Zumei (2003), Li Qingzhao ci xin shi ji ping. Zhongguo shudian, Beijing. (In Chinese).

Cipai. Lidai zuopin. Available at: https://sou-yun.cn/QueryCiTune.aspx (accessed: 21.11.2021) (in Chinese).

Deng Hongmei (2000), Nüxing ci shi. Shandong jiaoyu chubanshe, Jinan. (In Chinese).

Gao Mingquan (1992), "Songdai nüciren chuangzuo jianshu”. Guyuan shizhuan xuebao, 4 qi, di 18-21 ye. (In Chinese).

Hong Mai (1981), Yijian zhi (quan si ce). Zhonghua shuju chuban, Beijing. (In Chinese).

Hu Wenjie (1985), Lidai funü zhuzuo kao. Shanghai guji chubanshe, Shanghai. (In Chinese).

Hu Xiaoming (2016), Lidai nüxing shici jianshang cidian. Shanghai shiji chuban gufen youxian gongsi, Shanghai. (In Chinese).

Huzhou fu zhi. Available at: https://ctext.org/wiki.pl?if=gb\&chapter=978124\#p24 (accessed: 26.09.2021) (In Chinese).

Hua'an cixuan juan shi. Available at: https://ctext.org/wiki.pl?if=gb\&chapter= 749601\#p48 (accessed: 26.09.2021) (In Chinese).

Huang Huatong, Cai Guoqiang (2009), Shiyong Tang Song cipu. Beijing Daxue chubanshe, Beijing. (In Chinese).

Ke Baocheng (2009), Li Qingzhao quanji: hui ping ben. Chong wenshu ju, Wuhan. (In Chinese).

Liu Jingqi, Zhuge Yibing (1999), Zhongguo lidai mingjia liupai cichuan. Songdai nü ciren cichuan. Jilin renmin chubanshe, Changchun. (In Chinese).

Pingshui yun. Available at: https://sou-yun.cn/QR.aspx (accessed: 21.11.2021) (In Chinese).

Ren Rigao (1984), Songdai nü ciren pingshu. Taiwan shangwu yinshuguan, Xinbei. (In Chinese).

Shu Menglan (2001), Baixiang cipu (Xue ciren men di yi shu). Shanghai guji chubanshe, Shanghai. (In Chinese). 
Tang Guizhang (1965), Quan Song ci. Zhonghua shuju chuban, Beijing. (In Chinese).

Tang Song ci jianshang cidian: Nansong, Liao, Jin (2001), Shanghai cishu chubanshe, Shanghai. (In Chinese).

Tao Erfu, Liu Jingqi (1994), Nansong ci shi. Heilongjiang renmin chubanshe, Haerbin. (In Chinese).

Wang Donglin (2018), "Songdai nü ciren changyong yixiang xiade qinggan tiyan”. Wenxue jiaoyu (shang), (12), di 146-147 ye. (In Chinese).

Wang Zhaopeng, Liu Zunming (2003), Song ci da cidian. Fenghuang chubanshe, Nanjing. (In Chinese).

Wu Zhangshu (2016), Ci xue gaishuo. Zhonghua shuju, Beijing. (In Chinese).

Xia Chengdao, Wu Xionghe (2016), Du ci changshi. Zhonghua shuju, Beijing. (In Chinese).

Xia Chengdao (2008), Songci jianshang cidian. Shang ce. Shanghai cishu chubanshe, Shanghai. (In Chinese).

Xie Se (2010), Songdai nüxing ciren qunti yanjiu. Hunan renmin chubanshe, Changsha. (In Chinese).

Yang Wensheng (1981), Cipu jianbian. Sichuan renmin chubanshe, Chengdu. (In Chinese). 